\title{
Influence of the Smoking and Spitting Behaviors in Public Smoking Areas on the Microbial Contamination and Spread
}

\author{
Sung Woo Yang ${ }^{1, * \oplus} \cdot$ Seung Hyeon Reo ${ }^{1, * \oplus} \cdot$ Seung Jun Kim ${ }^{1, * \oplus} \cdot$ Jeong Wook Jo ${ }^{1, * \oplus} \cdot$

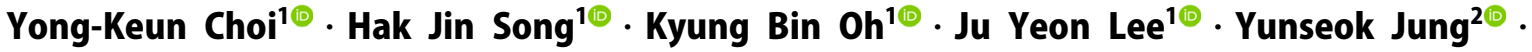 \\ Hyung Joo Kim ${ }^{1,+\odot}$
}

${ }^{1}$ Department of Biological Engineering, Konkuk University, Republic of Korea

${ }^{2}$ Department of Beauty \& Cosmetology Jeju University, Republic of Korea

(Received November 5, 2021; Revised November 29, 2021; Accepted November 29, 2021)

Objectives: The purpose of this study was to investigate the effect of spitting behavior on microbial public health in smoking areas. Through this investigation, bacterial concentration and spread of bacteria from the smoking areas were evaluated for the prospective public health and environment.

Methods: The number of spitting and the spitting location in the smoking areas were measured visually by observers. For the microbial analysis, filter papers $(5 \times 5 \mathrm{~cm})$ as sample collectors had been attached to the surface of the smoking areas for a given time. Using the collected filter paper, ATP bioluminescence measurement (RLU), colony forming unit (CFU) were measured. For the estimation of spitting behaviors in the smoking area on the spread microorganisms, saliva containing filters were selected from the areas, and fluorescent powder $\left(0.01 \mathrm{~g} / \mathrm{cm}^{2}\right)$ was added to the papers. After 4 hours, the papers around the smoking areas were collected and the fluorescence activity was measured.

Results and Discussion: The results showed that there was a clear relationship between the spitting behavior and the microbial activity in the smoking areas. In the case of sampling area A, the highest number of spitting was observed at the lunch hour (102 \pm 16 times), and the RLU from the sample collected near the smoking area showed about 5,139 $\pm 1,267$ RLU. When the RLU around the smoking area was measured, the lowest values were found at distance of 11 and $17 \mathrm{~m}$ from the cigarette bin (1,329 \pm 148 and 1,204 $\pm 203 \mathrm{RLU})$, and it was confirmed that smoking and spitting did not occur at this sampling points. In the case of sampling area B, the highest number of spitting (45 \pm 6 times) was observed at evening hour, and the RLU from the sample collected near the smoking area showed about 5,274 $\pm 1,297$ RLU. The lowest value was in the sampling area B shown at 11 and $18 \mathrm{~m}(1,181$ $\pm 243 \mathrm{RLU}$ and $1,148 \pm 168 \mathrm{RLU}$ ) from the cigarette bin, and it was also confirmed that smoking and spitting did not occur at this sampling points. The results indicate that the spitting during the smoking induced the increases of the microbial contamination of the public environment. The fluorescence powder diffusion analysis indicated that the saliva on the ground surface would enhance the spread of the microorganisms from the smoking area.

Conclusions: Spitting in smoking areas can pose a high risk of microbial infection for smokers and non-smokers in smoking areas. Thus extensive and systematic attention related to the smoking manner must be paid to protect our public health.

Keywords: Smoking area, Spitting behaviors, Pathogens, Bacterial spread, Public health

The Korean text of this paper can be translated into multiple languages on the website of http://jksee.or.kr through Google Translator. 


\title{
연구논문
}

\section{공공 흡연장에서의 흡연 중 침 뱉기가 흡연장 주변 바닥의 미생물 오염도 변화와 미생물 확산에 미치는 영향}

\author{
양성우 ${ }^{1 *} \cdot$ 여승현 $^{1, * \odot} \cdot$ 김승준 $^{1, * \odot} \cdot$ 조정욱 $^{1, *} \cdot$ 최용근 $^{1 \odot} \cdot$ 송학진 $^{1 \oplus} \cdot$ 오경빈 $^{1 \oplus} \cdot$ 이주연 $^{1 \oplus ~}$ \\ 정윤석 ${ }^{2} \cdot$. 김형주 ${ }^{1,+\odot}$
}

'건국대학교 공과대학 생물공학과

제주대학교 건강뷰티향장학과

목적 : 본 연구의 목적은 공공 흡연장에서 흡연 중 바닥에 직접 침을 뱉는 행위가 공중위생에 미치는 영향을 조사 하는 것이다. 이 연구를 통하여 향후의 공중위생과 환경을 위해 흡연장에서의 세균 농도와 세균의 확산을 평가하 였다.

방법: 흡연 구역에서 침 뱉는 횟수와 침 뱉는 위치를 관찰자들이 시각적으로 측정하였다. 미생물 분석을 위해 거 름종이 $(5 \times 5 \mathrm{~cm})$ 를 일정한 시간 동안 흡연 구역의 바닥 표면에 부착하여 샘플을 채취하였다. 샘플을 채취한 거름 종이를 이용하여 ATP bioluminescence (RLU), Colony forming unit (CFU)를 측정하였다. 흡연장에서 침 뱉는 행위 를 통한 미생물의 확산을 확인하기 위해 흡연장에서 침이 존재하는 거름종이를 선정하여 형광분말 $\left(0.01 \mathrm{~g} / \mathrm{cm}^{2}\right)$ 을 거름종이에 도포하였다. 4시간 후에 흡연장 주변의 거름종이를 수거하여 거름종이의 형광량(RFU, Relative Fluorescence Unit)을 측정하였다.

결과 및 토의: 흡연장 바닥의 침 뱉는 행위와 그에 따른 흡연장 바닥의 미생물 활성이 명확한 관계가 있다는 결 과를 보여주었다. 시료를 채취한 A 구역의 경우, 점심시간에 가장 많은 침 뱉는 횟수(102 \pm 16 회)가 흡연통 주변에 서 관찰되었다. 이때 흡연을 하면서 침을 뱉는 흡연통 근처의 15 개 구역에서 채취한 시료의 평균 RLU는 $5,139 \pm$ 1,267 로 측정되었다. 또한 흡연장 주변 RLU 측정 시, 흡연통으로부터 $11 \mathrm{~m}, 17 \mathrm{~m}$ 떨어진 곳에서 가장 낮은 값이 확인되었으며 $(1,329 \pm 148 \mathrm{RLU}, 1,204 \pm 203 \mathrm{RLU})$, 이 장소는 흡연 및 침 뱉기가 발생하지 않은 곳으로 확인되었 다. 시료를 채취한 $\mathrm{B}$ 구역의 경우는 저녁 시간에 가장 많은 침 뱉는 횟수( $45 \pm 6$ 회)가 관찰되었다. $\mathrm{B}$ 구역의 흡연 을 하면서 침을 뱉는 흡연통 근처 15 개의 장소 RLU는 5,274 $\pm 1,297 \mathrm{RLU}$ 로 측정되었으며, 흡연통에서 $11 \mathrm{~m}, 18$ $\mathrm{m}$ 떨어진 곳에서 가장 낮은 $\mathrm{RLU}(1,181 \pm 243 \mathrm{RLU}, 1,148 \pm 168 \mathrm{RLU})$ 가 측정되었다. 이 구역 또한 흡연 및 침 또한 뱉지 않은 구역으로 확인되었다. 이상의 결과는 침 뱉는 행위 및 바닥의 침이 흡연장 바닥의 미생물 오염도에 영향을 준다는 것을 보여주고 있다. 형광분말 확산 분석 결과는 흡연장 표면에서 침의 존재가 흡연장으로부터 다 른 지역으로 미생물의 확산을 유발할 수 있다는 것을 나타내고 있다.

결론 : 침을 뱉는 행위는 흡연장에 있는 흡연자들과 비흡연자들이 미생물에 감염될 수 있는 위험을 유발할 수 있 다. 따라서 공중위생을 안전하게 유지하기 위해서는, 흡연 중 침 뱉기의 위험성에 대한 설명과 주의가 필요하다고 판단된다.

주제어 : 흡연장, 침 뱉기, 병원성 미생물, 세균 확산, 공중위생

\section{1. 서 론}

2020년에 질병관리청에서 발표한 흡연 현황에 의하면, 우리 나라의 흡연율은 2019년을 기준으로 남자는 $35.7 \%$, 여자는 $6.7 \%$ 인 것으로 확인된다. 또한, 통계청의 조사결과에 따르면 국내 국민의 흡연율의 경우 남자는 2018 년에 비하여 $1.1 \% \mathrm{p}$ 감소해 1998년 이후로 가장 낮고, 여자는 2018년과 유사하다. ${ }^{1)}$
2018년에 서울연구원에서 발표한 금연구역과 흡연구역 현황 에 의하면 2018년 서울시를 기준으로 금연구역은 18,485 곳, 흡연구역은 79곳으로 나타났다. ${ }^{2}$ 이를 통해 국민들의 흡연 비 율에 비해 흡연구역은 현저히 적고, 그로 인해 사람들은 한정 된 구역에 모여서 흡연을 한다고 판단할 수 있다. 흡연장의 상황은 COVID-19 전후로 관찰되는 일상생활의 변화와 달리 전과 동일했다. 협소한 흡연구역 안에서 흡연자들은 마스크를 
내리고 흡연을 하는 것으로 나타난다. 심지어 카페나 $\mathrm{PC}$ 방 내에 있는 흡연장은 2 인 이상 입장금지를 시행함에도 불구하 고 2-3명씩 입장하여 흡연을 하는 것을 관찰할 수 있다.

흡연자와 비흡연자의 구강 내에 존재하는 세균을 동정해보 면 흡연자와 비흡연자 간의 구강 내 미생물의 분포에 큰 차이점 은 존재하지 않는다. ${ }^{3)}$ 그러나 타액 분비량은 흡연자의 경우가 많은 것으로 나타났다. ${ }^{4)}$ 이로 인해 흡연을 하는 사람들은 흡연 을 하는 과정에서 입 속에 생긴 침을 바닥에 뱉는 경우가 많다.

침에는 다양한 미생물이 존재한다. 다양한 환자들의 침 속 바이러스를 확인한 연구에 따르면, 에볼라 출혈열 환자로부터 에볼라 바이러스가 $)^{5}$, 인체 면역결핍 바이러스에 걸린 환자로 부터 인체 면역결핍 바이러스가 ${ }^{6}$, 다양한 환자 그룹으로부터 헤르페스 바이러스- 1 이 ${ }^{7}$, 재발성 편두통 환자로부터 인플루 엔자 A 바이러스가 발견되었다. ${ }^{8)}$ 심지어 입원 환자에서 광견 병 바이러스가 발견되고 ${ }^{9}$, 건강한 어른으로부터 헤르페스 바 이러스-6이 발견되었다. ${ }^{10)}$ 이와 같이 전염병에 걸린 사람뿐만 아니라 건강한 사람의 침에서도 전염병 바이러스가 존재할 수 있기에 불특정다수가 흡연장에서 뱉은 침에도 전염병을 일으키는 미생물이 존재할 가능성이 있다. 사람들이 감염병에 전파되는 경로는 매우 다양하고 그 중 공기매개를 통한 감염 은 예방하기가 쉽지 않다. 공기매개를 통한 감염은 대다수가 공기를 통해 전파되지만 일부는 침의 방울 형태인 비말을 통 해 전파된다. ${ }^{11)}$ 또한 에어로졸 입자를 통해 전염병에 감염될 가능성이 있다는 것도 이미 많은 연구를 통해 입증되었다. ${ }^{2)}$ 하지만 비말이나 에어로졸이 아닌 침을 통한 직접적인 전파사 례에 대해서는 명확하게 밝혀진 바가 없다.

따라서 본 연구에서는 흡연자가 흡연장 주변 바닥에 침을 뱉음으로써 발생할 수 있는 공중 위생상의 문제점을 확인하기 위하여, 국내 종합대학 내, 2 개소의 흡연장에서 흡연자가 흡 연 중 바닥에 침을 뱉는 횟수를 조사하고 주변의 시료를 채취 하여 ATP bioluminescence 기반 미생물의 오염도 및 $\mathrm{CFU}$ 의 측정을 진행하였다. 또한 형광분말을 이용하여 흡연자가 뱉은 바닥의 침이 미생물의 확산에 미치는 영향에 대한 추정을 진 행하였다.

\section{2. 재료 및 방법}

\section{1. 흡연장의 위치}

본 연구를 위하여 서울 소재 종합대학 내 2곳의 흡연장 $(\mathrm{A}$ 흡 연장: $37^{\circ} 32^{\prime} 26.1^{\prime \prime N}, 127^{\circ} 04^{\prime} 45.3^{\prime \prime} \mathrm{E}, \mathrm{B}$ 흡연장: $37^{\circ} 32^{\prime} 29.4^{\prime \prime} \mathrm{N}$, $\left.127^{\circ} 04^{\prime} 32.2^{\prime \prime} \mathrm{E}\right)$ 을 선정하고, 선정된 흡연장에서의 침 뱉는 횟 수 분석, 미생물 분석 및 형광물질 확산 실험을 실시하였다.

\section{2. 시약}

본 실험에서는 거름종이(CAT No. 1002-110, GE Healthcare Life Science Whatman ${ }^{\mathrm{TM}}, \mathrm{UK}$ )를 사용하여 시료채취를 진행
하였다. 배지(Bacto ${ }^{\mathrm{TM}}$ Tryptic Soy Broth soybean-Casein Digest Medium, Becton, Dickinson and Company, USA) 와 한천(Agar, Samchun Pure Chemical, Korea) 등을 사용하여 미 생물 $\mathrm{CFU}$ 분석을 진행하였으며, 생물발광법 기반 미생물 오 염도 분석(ATP bioluminescence measurement) 은 ATP 표면 스왑 키트(Clean-Trace ${ }^{\mathrm{TM}}$ Test, $3 \mathrm{M}$ Health Care, USA)를 이용 하여 측정하였다. 흡연장에서의 타액으로 인한 미생물 확산 범위는 분말형광안료(2388384969, Petit Art, Japan)를 이용하 여 excitation 파장 $490 \mathrm{~nm}$, Emission 파장 $590 \mathrm{~nm}$ 에서 분석하 였다.

\section{3. 실험 기간}

흡연장에서 흡연 및 침 뱉는 횟수의 측정 등, 흡연자 관찰 분석은 3 명의 관찰자 $(\mathrm{A}, \mathrm{B}, \mathrm{C})$ 가 육안으로 진행하였다. 우선 주변 건물 옥상에서 흡연장 주변을 사진 촬영하여 간이 지도 를 만들고, 지도상에 실 거리 $1 \mathrm{~m}$ 단위로 격자를 표시하였다. 관찰자 중 $\mathrm{A}$ 와 $\mathrm{B}$ 는 흡연장을 중심으로 약 $50 \mathrm{~m}$ 떨어진 각각 의 지점에서 흡연 위치와 침 뱉은 위치를 확인하였다. 관찰자 $\mathrm{C}$ 는 흡연장 방문자의 수와 침 뱉은 횟수를 기록하였으며, 추 가적으로 흡연장 근처를 지나간 유동인구수도 기록하였다. 흡 연장에서의 관찰자 위치 등은 Fig. 1에 표시하였다.

실험기간은 2021년 4-5월이였으며, 우천일과 그 다음날 을 피하여 진행하였다. 흡연자 관찰 분석 진행은 각각의 흡 연장 실험장소에서 유동인구, 흡연자 수, 침 뱉는 횟수, 침 뱉은 위치 등을 조사하였으며, 측정 시간대는 9:30 10:30, 12:30 13:30, 17:00 18:00으로 나누어 1일 3회로 설정하였다. 관찰분석은 1 주에 1 일(1일 3 회), 4 주간에 걸쳐 총 12 회에 걸쳐 진행하였으며, 미생물 및 형광 분석 실험은 상기 흡연자 수 분석일과 동일한 일자에 총 4 회 진행하였다. 미생물 및 형광 실험 분석은 동일 시료를 3 회 이상 측정하여 결과를 산출하였 다. 수치분석은 통계 프로그램인 SPSS (Ver. 25)를 사용하여 구하였다.

\section{4. 미생물 분석 시료의 채취}

미생물 분석용 시료를 흡연장 주변 지면에서 채취하기 위하 여, 거름종이를 사용하였다. ${ }^{13)}$ 각 흡연장을 기준으로 전체 측 정 범위를 정하고, 이를 $1 \mathrm{~m} \times 1 \mathrm{~m}$ 단위로 구역을 나누었다. $5 \mathrm{~cm} \times 5 \mathrm{~cm}$ 의 거름종이를 양면테이프를 이용하여 각 구역의 중앙부 바닥에 1 장씩 부착하였다. 이때 양면테이프는 거름종 이의 가장자리 네 군데에 부착하였다. 양면테이프가 부착된 거름종이는 각 실험장에서 흡연자 관찰분석이 진행되는 실험 일자 오전 10 시에 각각의 흡연장 바닥에 부착하고, 오후 4시 에 수거하였다. 수거된 거름종이는 중앙에 $1 \mathrm{~cm} \times 2 \mathrm{~cm}$ 의 구멍이 있는 하드보드지(규격 $4 \mathrm{~cm} \times 4 \mathrm{~cm}$ )와 $70 \%$ 에탄올로 소독을 진행한 surgical blade로 중앙부분에 해당되는 거름종 이를 잘라낸 후 이를 분석에 사용하였다. 이 과정을 Fig. 1 에 


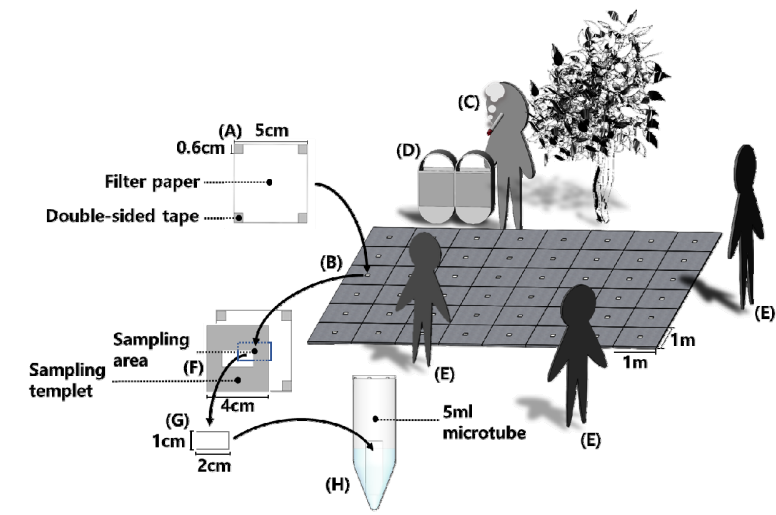

Fig. 1. The schematic illustration of the experiments in the smoking area: (A) filter paper for the sampling, (B) smoking area, (C) smoker(s), (D) cigarette bin, (E) observers, (F) sampling templet, $(G)$ microtube for the analysis.

표시하였다.

\section{5. 생물 발광법을 이용한 미생물 오염도 측정}

생물발광분석법 ${ }^{14)}$ 을 이용하여 채취된 거름종이 시료의 미 생물 오염도를 측정하였다. 분석을 위하여 채취한 시료를 5 $\mathrm{ml}$ microtube에 넣은 후 증류수(D.W) $2 \mathrm{ml}$ 를 첨가하여 1 분 30 초간 vortex mixer를 이용하여 혼합을 하였다. 혼합한 시료 $2 \mathrm{ml}$ 중 $1 \mathrm{ml}$ 를 $\mathrm{ATP}$ 측정기(Clean-Trace ${ }^{\mathrm{TM}} \mathrm{NG}$ Luminometer, 3M Deutschland GmbH-Health Care Business, Germany)를 이 용하여 RLU (Relative Luminescence Unit)를 측정하였으며, 동일한 실험을 3 회 반복하였다. 혼합한 시료 $2 \mathrm{ml}$ 중 $1 \mathrm{ml}$ 를 사용하고 남은 $1 \mathrm{ml}$ 의 시료는 $\mathrm{CFU}$ 측정에서 사용하였다.

\section{6. 시료의 CFU 측정}

RLU값과 CFU (Colony Forming Unit) 사이의 상관관계를 확인하기 위하여 총 4회의 RLU 측정을 통해 각 흡연장에서 $\mathrm{RLU}$ 가 가장 높았던 2곳과 RLU가 가장 낮았던 2곳을 선정하 여, 총 4 개의 시료를 채취한 후 미생물 오염도 측정에 사용하 고 남은 $1 \mathrm{ml}$ 의 시료 중, $100 \mu \mathrm{l}$ 씩 $\mathrm{TSA}$ 배지 3 개에 도말한 후 $35^{\circ} \mathrm{C}$ 에서 48 시간 동안 배양을 진행하였다. ${ }^{15)} 48$ 시간동안 배양을 진행한 후, 각 시료의 RLU 값과 $\mathrm{CFU}$ 를 비교하였다.

\section{7. 형광 분말을 이용한 미생물 확산도 분석}

흡연장에서 흡연자가 뱉은 침은 흡연장을 지나가는 사람들 이 밟게 되고, 이를 통하여 신발에 묻은 침은 사람들이 이동하 며 다른 곳으로 확산된다. 이를 확인하고, 그 확산 정도를 분 석하기 위하여 형광분말을 이용하여 실험을 진행하였다. 우선 흡연장 $\mathrm{A}$ 와 $\mathrm{B}$ 에 시료 채취용 거름종이를 2.4절에서의 미생물 분석과 동일한 방식으로 부착하였다. 각 실험일자의 오전 9시 에 부착 후 방치하여 흡연자가 뱉은 침이 거름종이에 묻도록
하였다. 3 시간 경과 후 흡연통에 근접한 침이 묻은 시료채취 용 거름종이 3 개를 선정하여 형광분말을 $0.01 \mathrm{~g} / \mathrm{cm}^{2}$ 를 도포하 였다. 거름종이를 각 실험 일자의 오후 16 시까지 방치하여 사 람들이 충분히 거름종이를 밟고 지나가게 한 뒤, 각 실험 일 자의 오후 16 시에 거름종이를 2.4 절에 언급한 방식으로 채취 하여 2.5절과 같은 방식으로 증류수를 추가하고 혼합하였다. 미생물의 확산 범위를 조사하기 위해 형광물질이 방출하는 빛인 형광을 정량분석 할 수 있는 형광광도계(SpectraMax M2, Molecular Devices, USA)를 이용하여 Relative Fluorescence Unit (RFU)을 측정하였다. ${ }^{16)}$ 혼합된 시료들을 96 well에 옮긴 후, 96 well을 형광광도계로 excitation 파장은 $490 \mathrm{~nm}$ 으로, Emission 파장은 $590 \mathrm{~nm}$ 으로 설정하여 시료들을 동시에 분석 하였으며, 동일한 실험을 3 회 반복하였다. 대조군으로써, 측정 거리를 $53 \mathrm{~m}$ 로 연장하여, 흡연장에서 침이 묻지 않은 거름종 이에 형광분말을 도포하고, 그 외 조건을 동일하게 진행하여 형광분말이 타액으로 인해 확산된 것인지를 확인하였다. 모든 실험은 3 회 이상 반복하여 그 결과의 평균값을 사용하였다.

\section{3. 결과 및 고찰}

\section{1. 흡연장 방문자수, 방문자 중 흡연인원, 흡연 중 침 뱉는 횟수 및 유동인구 분석}

$\mathrm{A}$ 흡연장과 $\mathrm{B}$ 흡연장에서의 유동인구, 흡연자 수, 침 뱉는 횟수의 총합을 Fig. 2에 표기하였다. A 흡연장과 B 흡연장에 서, 흡연장 유동인구 10 명 중 8 명 $(80.55 \pm 5.51 \%)$ 는 흡연자로 나타났으며, 흡연자 중 10 명 중 7 명 $(67.12 \pm 9.27 \%)$ 가 침을 뱉는 것으로 확인된다. 또한 침 뱉는 흡연자 1명당 3.5 회(3.54 \pm 0.81 ) 침을 뱉는 것으로 나타났다.

$\mathrm{A}$ 흡연장에서 실험 일자의 11:30 12:30에서 유동인구가 가 장 많았고 그에 따라 흡연자 수, 침 뱉는 횟수의 총합 모두 가장 높았다. 이를 직접 관찰한 결과, 점심시간에 식사를 하러 외출하는 인원뿐만 아니라 배달음식으로 인한 배달원들의 왕 래 및 출근 인구에 의한 것으로 보인다. 반면 실험 일자의 9:30 10:30에서 유동인구, 흡연자 수, 침 뱉는 흡연자 수, 침 뱉는 횟수의 총합 모두 가장 낮았다. 이는 $\mathrm{A}$ 흡연장이 소재하 고 있는 건물 관련 인원의 평균적인 출근시간이 $10: 30$ 분 이후 라는 점에 의한 것으로 보인다.

$\mathrm{B}$ 흡연장에서는 유동인구, 흡연자 수, 침 뱉는 횟수의 총합 모두 실험 일자의 17:00 18:00에서 가장 높았다. 이는 B 흡연 장이 소재한 건물에 도서관이 있고, 대다수의 학생 및 직원들 의 해당 건물 이용 시간대가 17:00 18:00라는 점에 의한 것으 로 보인다. 반면 실험 일자의 11:30 12:30에서 유동인구, 흡연 자 수, 침 뱉는 흡연자 수, 침 뱉는 횟수의 총합 모두 가장 낮았 다. 이는 B 흡연장이 소재하고 있는 건물에서 11:30 12:30에 서 일반적으로 강의가 진행되기에 대부분의 인구가 해당 시간 대에 건물 내에 있음에 의한 것으로 보인다. 따라서 흡연장에 
(A)

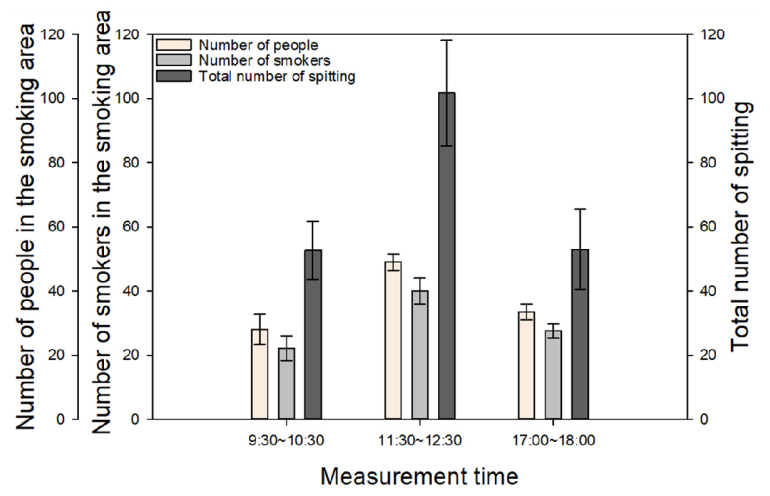

(B)

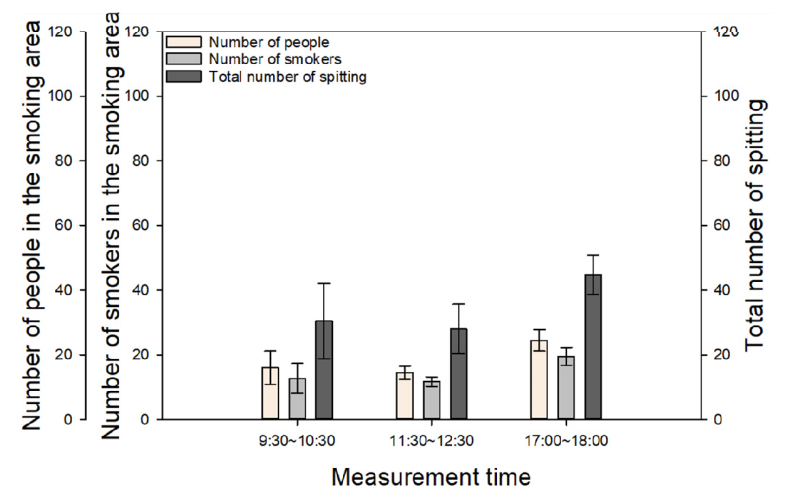

Fig. 2. Average numbers of visitors and smokers, number of spitting during smoking in the smoking area: $(A)$ is the smoking area located at $37^{\circ} 32^{\prime} 26.1^{\prime \prime} \mathrm{N}, 127^{\circ} 04^{\prime} 45.3^{\prime \prime} \mathrm{E}$, and $(B)$ is the smoking area located at $37^{\circ} 32^{\prime} 29.4^{\prime \prime} \mathrm{N}$, $127^{\circ} 04^{\prime} 32.2^{\prime \prime} \mathrm{E}$.

서의 침 뱉는 횟수는 시간대에 관계없이 흡연자의 수에 비례 하고 있음을 나타내고 있다.

$\mathrm{A}$ 와 $\mathrm{B}$ 흡연장에서 침 뱉은 위치와 횟수에 대한 결과를 Fig. 3 에 표시하였다. $\mathrm{A}$ 흡연장의 경우 침 뱉은 구역은 대부분 흡 연통과 근접한 구역이며 침 뱉은 횟수 또한 흡연통과 근접한 구역에서 증가하는 모습을 보여준다. 이는 사람들이 담배꽁초 를 쉽게 버리기 위해 흡연통 주변에서 흡연하는 경향에 의한 것으로 보이며, 그 주변 구역이 유동인구가 많기에 그에 따라 침 뱉는 횟수도 증가하는 것으로 보인다. $\mathrm{B}$ 흡연장은 침 뱉은 구역이 대부분 흡연통에 근접한 구역이며 침 뱉은 횟수는 특 정 구역을 제외하고는 유사하게 나타났다. B 흡연장의 경우 흡연통의 앞과 뒤에 화단이 존재하여 흡연통에 접근하는 길이 두 곳이다. 그곳의 흡연자들을 관찰한 결과, 건물과 더 가까운 방향에 있는 왼쪽 구역에서 담배를 많이 피우는 경향이 있어 왼쪽에서 침 뱉은 횟수가 많은 것으로 보인다.

\section{2. 흡연장 주변 바닥에서의 RLU측정을 통한 미생물 오염도 및 $\mathrm{CFU}$ 확인}

흡연장 바닥에서의 미생물 활성 분석을 위하여, 흡연장 바 닥에 거름종이를 부착 후 일정 시간이 지난 후, 채취한 시료의 $\mathrm{RLU}$ 를 측정하여 Fig.3에 표시하였다. 또한 이 결과를 미생물
(A)

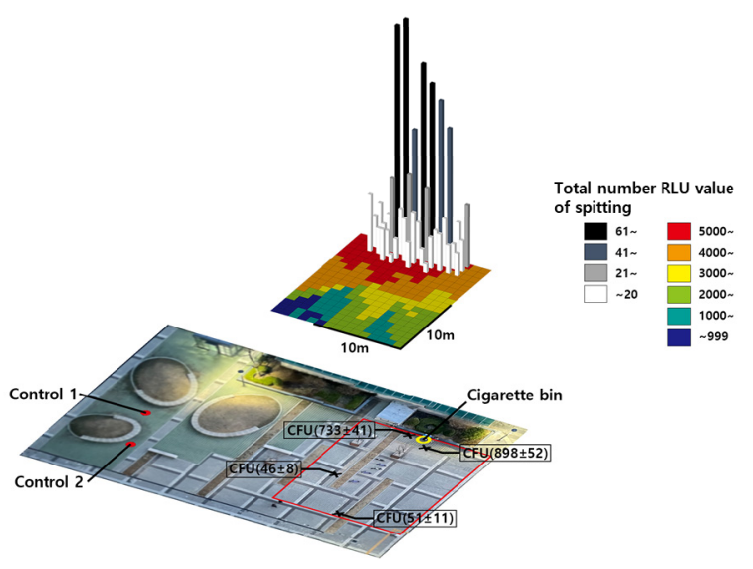

(B)

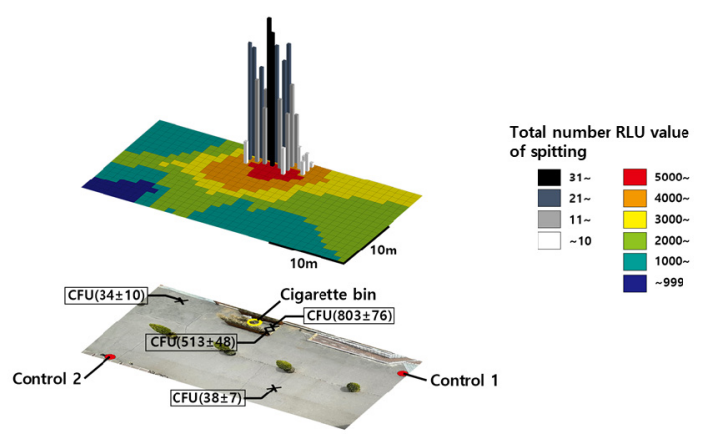

Fig. 3. The relationship among RLU values, the number of spitting, and CFU in the smoking areas A and B. The control areas and the cigarette bins are indicated at the maps (the bottom layers of the illustrations).

의 존재여부와 비교하기 위하여, RLU 실험에서 값이 가장 높 았던 흡연통 근처 2곳과, RLU 값이 가장 낮았던 흡연통 바깥 의 2곳을 선정하여 $\mathrm{CFU}$ 를 측정하였다. 또한 침이 미생물의 증식에 영향을 주는지 확인하기 위해 흡연을 하지만 침을 뱉 지 못하게 한 2 곳(Fig.3의 control)에서도 $\mathrm{CFU}$ 를 확인하였다. 각 흡연장에서 모두 6곳을 선정하여 채취한 시료를 TSA배지 에 $100 \mu \mathrm{l}$ 도말하고 $35^{\circ} \mathrm{C}$ 에서 48 시간 배양하여 $\mathrm{CFU}$ 를 확인 하였다.

$\mathrm{A}$ 흡연장의 경우, 흡연을 하며 침을 많이 뱉는 흡연통 근처 15 개의 구역에서의 평균 RLU는 $5,139 \pm 1,267$ 로 측정되었다. $\mathrm{RLU}$ 측정 지역 중 RLU가 가장 높았던 두 구역은 흡연통에서 반경 $2 \mathrm{~m}$ 이내의 구역으로 RLU가 $6,475 \pm 749$ 및 $6,994 \pm$ $596 \mathrm{RLU}$ 로 나타났으며, 각 구역에서의 $\mathrm{CFU}$ 는 $733 \pm 41$ 및 $898 \pm 52 \mathrm{CFU} / \mathrm{cm}^{2}$ 으로 각각 측정되었다. $\mathrm{RLU}$ 측정 지역 중 $\mathrm{RLU}$ 가 가장 낮았던 두 구역은 흡연통에서 약 $11 \mathrm{~m}, 17 \mathrm{~m}$ 떨어진 구역으로 RLU가 각각 $1,329 \pm 148$ 및 $1,204 \pm 203$ $\mathrm{RLU}$ 로 나타났으며, 각 구역에서의 $\mathrm{CFU}$ 는 $51 \pm 11$ 및 $46 \pm$ $8 \mathrm{CFU} / \mathrm{cm}^{2}$ 으로 측정되었다. 이 구역은 관찰 분석 결과, 흡연 을 하지 않으며 침 또한 뱉지 않는 구역으로 확인되었다. 침을 많이 뱉는 흡연통과 거리가 먼 곳의 RLU 및 CFU는 흡연통 주변 구역과 비교하였을 때, 모두 낮은 측정값을 보여주고 있 
다. 이 경우 RLU가 높은 구역과 낮은 구역에서의 $\mathrm{CFU} / \mathrm{cm}^{2}$ 이 대략 16.9 배의 차이를 나타내는 것을 확인하였다. 침이 미생 물 오염도에 영향을 주는지 확인하기 위한 대조 실험으로써, 기존의 흡연통에서 $30 \mathrm{~m}$ 및 $31.5 \mathrm{~m}$ 떨어진 위치(Fig.3의 (A) 에서 Control로 표시한 위치)를 설정하고, 관찰기간 동안 그 구역에서 흡연 중 침을 뱉지 못하도록 관찰자가 유도한 뒤, $\mathrm{RLU}$ 를 두 곳에서 측정한 결과, $546 \pm 51 \mathrm{RLU}, 712 \pm 66 \mathrm{RLU}$ 로 나타났다. 흡연을 하지만 침을 뱉지 못한 곳과 흡연을 하면 서 침을 많이 뱉은 흡연통 주변 구역을 비교하면 RLU 값은 약 $86.5 \%$ 감소하였다. 또한 두 곳에서의 $\mathrm{CFU}$ 를 측정한 결과 $7 \pm 2$ 및 $14 \pm 2 \mathrm{CFU} / \mathrm{cm}^{2}$ 으로 측정되었다. 이는 흡연통 근처 에서의 $\mathrm{CFU} / \mathrm{cm}^{2}$ 과 비교하였을 때 $1.29 \%$ 에 해당하는 수치로 침이 없는 경우에는 미생물이 많이 존재하지 않는다고 판단 된다.

$\mathrm{B}$ 흡연장에서도 동일하게 흡연을 하며 침을 많이 뱉는 흡연 통 근처 15 개의 구역에서 평균 RLU가 5,274 $\pm 1,297 \mathrm{RLU}$ 로 측정되었다. RLU 측정 지역 중 RLU가 가장 높았던 두 구역 은 흡연통에서 반경 $2 \mathrm{~m}$ 이내의 구역으로 RLU가 5,373 540 및 6,638 $\pm 1,086 \mathrm{RLU}$ 로 나타났으며, 각 구역에서의 $\mathrm{CFU}$ 는 $513 \pm 48$ 및 $803 \pm 76 \mathrm{CFU} / \mathrm{cm}^{2}$ 으로 측정되었다. $\mathrm{RLU}$ 측정 지역 중 RLU가 가장 낮았던 두 구역은 흡연통에서 약 $11 \mathrm{~m}, 18 \mathrm{~m}$ 떨어진 구역으로 RLU가 $1,181 \pm 243$ 및 1,148 $\pm 168 \mathrm{RLU}$ 로 나타났으며, 각 구역에서의 CFU는 $34 \pm 10$ 및 $38 \pm 8 \mathrm{CFU} / \mathrm{cm}^{2}$ 으로 측정되었다. 이 구역은 관찰 분석 결과, 흡연을 하지 않으며 침 또한 뱉지 않는 구역으로 확인되었다. 이 경우도 역시, 침을 많이 뱉는 흡연통과 거리가 멀기 때문에 흡연통 주변 구역과 비교하여 적은 $\mathrm{RLU}, \mathrm{CFU} / \mathrm{cm}^{2}$ 수치를 보 여주고 있다. B 흡연장에서도 A 흡연장과 비슷하게 RLU가 높은 구역과 낮은 구역에서의 $\mathrm{CFU} / \mathrm{cm}^{2}$ 이 대략 18.4 배의 차이 를 나타내는 것을 확인하였다. 침이 미생물 오염도에 영향을 주는지 확인하기 위한 대조 실험으로써, 기존의 흡연통에서 $12 \mathrm{~m}$ 및 $23 \mathrm{~m}$ 떨어진 위치(Fig.3의 (B)에서 Control로 표시한 위치)를 설정하고, 관찰기간 동안 그 구역에서 흡연 중 침을 뱉지 못하게 한 뒤, $\mathrm{RLU}$ 를 두 곳에서 측정한 결과, $752 \pm$ 53 및 $656 \pm 49 \mathrm{RLU}$ 로 나타났다. 흡연을 하지만 침을 뱉지 못한 곳과 흡연을 하면서 침을 많이 뱉은 흡연통 주변 구역을 비교하면 대략 $85.7 \%$ 감소하였다. 또한 두 곳에서의 $\mathrm{CFU}$ 를 측정한 결과 $20 \pm 2$ 및 $16 \pm 3 \mathrm{CFU} / \mathrm{cm}^{2}$ 으로 측정되었다. 이는 흡연통 근처에서의 $\mathrm{CFU} / \mathrm{cm}^{2}$ 과 비교하였을 때 $2.68 \%$ 에 해당 하는 수치로 침이 없는 경우에는 미생물이 많이 존재하지 않 는다고 판단된다.

두 흡연장에서 유사하게 유동인구가 많이 존재하고 침 뱉는 횟수가 많은 흡연통 주변 구역이 흡연통 바깥 구역과 침을 뱉지 않은 흡연 공간보다 높은 RLU 수치와 $\mathrm{CFU} / \mathrm{cm}^{2}$ 을 나타 냈다. 즉, 침을 많이 뱉은 곳이 RLU값이 높으며 이는 많은 미생물이 존재하기 때문에 높은 값의 $\mathrm{CFU}$ 가 관찰될 수 있으
며 ${ }^{17,18,19)}$, 반대로 침을 뱉지 않는 곳은 RLU값이 낮으며 동시 에 낮은 값의 $\mathrm{CFU}$ 가 나타났다고 판단된다. 동일하게 사람들 이 많이 다니기는 하지만 흡연통과 거리가 먼 구역 및 흡연을 하지만 침을 뱉지 못하게 한 구역(control 위치)에서는 흡연통 주변 구역에 비해 적은 $\mathrm{RLU}$ 및 $\mathrm{CFU} / \mathrm{cm}^{2}$ 수치를 나타냈다. 따라서 이상의 결과는 흡연 중 침을 뱉는 행위로 인한 침의 존재가 미생물이 증식하게 해줄 뿐만이 아니라 주변으로 확산 될 수 있게 큰 영향을 준다고 판단된다.

\section{3. 흡연자의 타액이 형광물질 확산에 미치는 영향}

각 흡연장에서 흡연자의 타액에 첨가한 형광물질의 확산 범 위를 확인한 결과를 Fig.4에 표시하였다. A 흡연장의 경우 흡연통을 기준으로 $3 \mathrm{~m}, 23 \mathrm{~m}$ 떨어진 구역에서의 RFU는 각 각 $1,985 \pm 213$ 및 $82 \pm 20 \mathrm{RFU}$ 로 측정되었다. $20 \mathrm{~m}$ 의 거리가 떨어지면 $4.13 \%$ 의 형광이 남아있었다. 흡연장 지도 범위 내에 서, 흡연장은 아니지만 흡연을 한 곳에서 침을 뱉지 못하게 한 뒤, 두 곳(Fig.4의 (A)에서 Control로 표시한 위치)에서 시 료를 채취했을 때는 각각 $0.74 \pm 0.05$ 및 $0.98 \pm 0.08 \mathrm{RFU}$ 로 측정되었다.

$\mathrm{B}$ 흡연장에서 타액이 존재하는 경우에 형광의 확산 범위를 확인한 결과, $\mathrm{A}$ 흡연장에서 확인한 결과와 같이 처음 확산이 시작한 지 $3 \mathrm{~m}$ 후의 $\mathrm{RFU}$ 를 $100 \%$ 로 두었을 때 거리가 멀어질 수록 $\mathrm{RFU}$ 가 줄어드는 것을 확인할 수 있다. $\mathrm{B}$ 흡연장의 경우 흡연통을 기준으로 $3 \mathrm{~m}, 28 \mathrm{~m}$ 떨어진 구역에서의 RFU는 각 각 2,127 \pm 284 및 $49 \pm 21 \mathrm{RFU}$ 로 측정되었다. $25 \mathrm{~m}$ 의 거리가

(A)

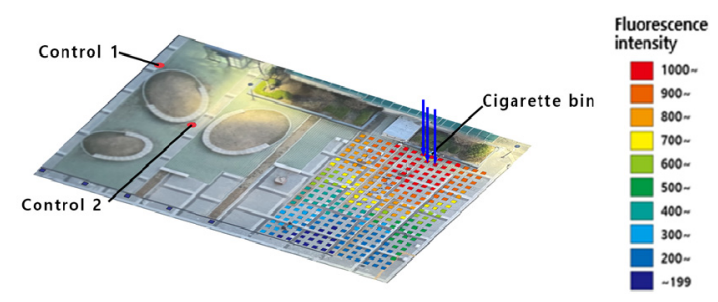

(B)

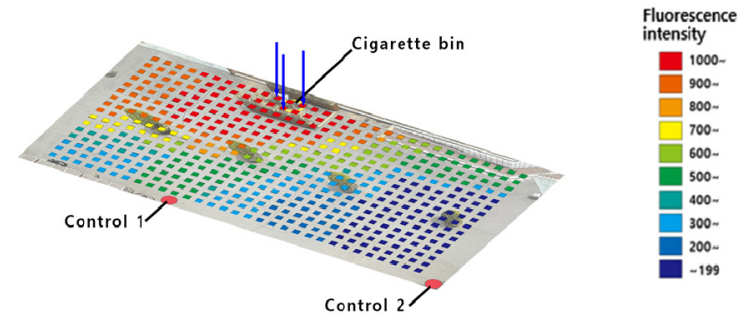

Fig.4. Diffusion of the fluorescence powder from the smoking areas $A$ and $B$. The squares in the maps shows the fluorescence intensity of the sampling papers. The blue lines indicate the fluorescence powder addition points. The control areas and the cigarette bins are indicated at the maps. 
떨어지면 $2.3 \%$ 의 형광이 남아있었다. 흡연장 지도 범위 내에 서 흡연장은 아니지만 흡연을 하는 곳에서 침을 뱉지 못하게 한 뒤 두 곳(Fig. 4의 (B))에서 Control로 표시한 위치)에서 시료를 채취했을 때는 각각 $0.66 \pm 0.05$ 및 $0.82 \pm 0.07 \mathrm{RFU}$ 로 측정되었다.

시료 분석용 거름종이에 타액이 존재하는 경우는 $\mathrm{A}$ 와 B 흡 연장소에서 모두 형광물질이 $50 \mathrm{~m}$ 이상 확산됨을 알 수 있었 다. 구체적으로 침이 존재하는 경우에는 $3 \mathrm{~m}$ 떨어진 거름종이 에서 평균 2,029 $\pm 121 \mathrm{RFU}$ 로 측정되었고, $53 \mathrm{~m}$ 떨어진 거름 종이에서는 $119 \pm 19 \mathrm{RFU}$ 로 측정되었다. 침이 존재하는 경우 에는 거리가 $50 \mathrm{~m}$ 멀어지면 $5.85 \%$ 의 형광이 잔존하였다. 그 러나 침이 존재하지 않을 경우에는 $3 \mathrm{~m}$ 떨어진 거름종이에서 $1,426 \pm 151 \mathrm{RFU}$ 로 측정되었으며, $53 \mathrm{~m}$ 떨어진 거름종이에 서는 $28 \pm 5 \mathrm{RFU}$ 로 측정되었다. 침이 존재하지 않는 경우에 는 거리가 $50 \mathrm{~m}$ 멀어지면 $1.99 \%$ 의 형광이 잔존하였다. 채취 한 시료들의 $\mathrm{RFU}$ 를 수치상으로 비교하였을 때, 침이 묻은 시 료는, 침이 묻지 않은 시료보다 동일 거리 $(50 \mathrm{~m})$ 에서 약 2.94 배 이상 형광분말이 잔존할 수 있음을 보여주고 있다. 이와 같은 결과는 흡연자가 뱉은 침이 형광물질의 확산에 큰 영향 을 주며, 앞서 진행한 RLU와 $\mathrm{CFU}$ 결과와 연계하여 볼 때 흡연자의 침이 공중 보건과 깊은 관련이 있고, 미생물에서의 분포 및 그 확산에 직접적으로 연관이 있음을 확인할 수 있 었다.

\section{4. 결 론}

본 연구의 결과, 흡연장에서 뱉는 침이 미생물의 흡연장 주 변의 미생물 농도와 미생물의 확산에 영향을 주고 있음을 확 인하였다.

1) ATP bioluminescence 측정 기반 RLU를 측정한 결과, 흡 연장 주변 구역이 흡연장에서 거리가 먼 구역보다 높은 값이 측정되는 경향이 나타났다. $\mathrm{A}$ 흡연장 주변 구역에서는 5,139 $\pm 1,267 \mathrm{RLU}$, 흡연장에서 거리가 $11 \mathrm{~m}, 17 \mathrm{~m}$ 떨어진 곳에서 는 1,329 \pm 148 및 $1,204 \pm 203 \mathrm{RLU}$ 로 측정되었다. B 흡연장 도 유사하게 흡연장 주변 구역에서 5,274 $\pm 1,297 \mathrm{RLU}$, 흡연 장에서 거리가 $11 \mathrm{~m}, 18 \mathrm{~m}$ 떨어진 곳에서는 각각 $1,181 \pm$ 243 및 $1,148 \pm 168 \mathrm{RLU}$ 로 측정되었다. 또한 A 흡연장과 B 흡연장의 지도 범위 내에서 흡연 구역이 아닌 곳에서 담배를 피우는 사람들에게 침을 뱉지 못하게 한 뒤(대조군), RLU를 측정하였을 때 $\mathrm{A}$ 흡연장은 $546 \pm 51$ 및 $712 \pm 66 \mathrm{RLU}, \mathrm{B}$ 흡연장은 $752 \pm 53$ 및 $656 \pm 49 \mathrm{RLU}$ 로 각각 측정되었다. 이 결과를 통해 침을 뱉는 행위가 흡연장 주변 미생물 오염도 에 영향을 줄 수 있음을 확인하였다.

2) TSA 배지를 이용해 미생물을 배양하여 CFU를 확인해본 결과, 침이 많았던 흡연장 주변 구역에서 $\mathrm{CFU}$ 가 높게 측정되 었다. 반면에 흡연장과 거리가 멀었던 구역에서는 $\mathrm{CFU}$ 가 낮
게 측정되었다. 두 흡연장에서 흡연장 주변 구역과 흡연장에 서 거리가 먼 구역에서의 $\mathrm{CFU}$ 가 차이가 나타났다. 침 속에는 미생물이 생장하는 데 필요한 다양한 영양소(탄수화물, 단백 질, 아미노산, 핵산, 비타민, 보조인자 등)가 존재한다. ${ }^{20)}$ 또한 침의 특성상 다양한 물질의 부착이 가능하기 때문에 침을 많 이 뱉은 흡연장 주변 구역에서 다양한 미생물이 많이 생장한 것으로 볼 수 있다.

3) 형광물질을 이용한 확산실험의 경우, 거리가 멀어질수록 $\mathrm{RFU}$ 가 점차 줄어드는 추세를 확인하였다. 두 흡연장에서 침 이 존재하는 경우에 형광의 확산을 확인했을 때, 거리가 멀어 질수록 형광이 적게 남아있었다. 또한 거리를 늘려 침이 존재 하는 경우와 존재하지 않는 경우에 형광의 확산을 확인했을 때, 침이 존재하는 경우가 같은 거리에서 더 많은 형광이 남아 있고, 동일한 양의 형광이 남아있을 때의 거리를 비교하면 침 이 존재하는 경우가 더 멀리 이동한 것을 확인했다. 형광을 이용해 침이 $50 \mathrm{~m}$ 이상 이동이 가능하며, RLU와 $\mathrm{CFU}$ 결과를 토대로 미생물의 경우에도 동일하게 적용될 것이라 판단된다.

4) 이와 같은 실험을 통해 흡연장 바닥에 미생물이 존재하 는 것을 확인했으며, 특히 침에 있는 미생물들이 사람들이 침을 밟고 지나감에 따라 확산되었음을 확인하였다. 침 속 미생물군은 사람마다 상이하며, 여러 병원성 미생물들이 존 재할 수 있기 때문에 흡연장에서 담배를 피우면서 침 뱉는 행위를 자제하는 것이 공중위생 및 보건상 꼭 필요하다고 판 단된다.

5) 본 연구의 결과는, 특정 대학교 내에 존재하는 한정적인 인원이 사용하는 흡연 구역에서 4-5월에 걸쳐 진행하였기 때 문에, 더 많은 유동인구가 사용하는 일반적인 도로변에 존재 하는 흡연 구역의 결과와 다를 수 있어 이에 대한 추가적인 연구가 필요하다.

\section{Acknowledgement}

이 연구는 2021학년도 건국대학교의 드림학기제에 의해 지 원되었습니다. 이에 감사드립니다.

\section{References}

1. Korea Disease Control and Prevention Agency Home page, http://www.kdca.go.kr (2020).

2. The Seoul Institute Home page, http://www.si.re.kr (2019).

3. H. J. Jeong, S. J. Kim, Distribution and antimicrobial susceptibility of bacteria in the oral cavity of smokers or non-smokers, Korean J. Microbiol., 46(4), 334-340(2010).

4. J. H. Kim, G. U. Kim, Effect of oral environment (salivary flow, taste recognition threshold) of adults over 40 years on oral health influence point (OHIP-14), J. Korean Soc Dent Hyg, 13(5), 749-757(2013). 
5. D. G. Bausch, J. S. Towner, S. F. Dowell, F. Kaducu, M. Lukwiya, A. Sanchez, S. T. Nichol, T. G. Ksiazek, P. E. Rollin, Assessment of the risk of Ebola virus transmission from bodily fluids and fomites, J. Infect. Dis., 196(Supplement_2), S142-S147(2007).

6. D. H. Coppenhaver, P. S. Woo, S. Baron, C. E. Barr, M. N. Qureshi, Correlation of nonspecific antiviral activity with the ability to isolate infectious HIV-1 from saliva, NEJM, 330(18), 1314-1315(1994).

7. K. Tateishi, Y. Toh, H. Minagawa, H. Tashiro, Detection of herpes simplex virus (HSV) in the saliva from 1,000 oral surgery outpatients by the polymerase chain reaction (PCR) and virus isolation, J. Oral Pathol. Med., 23(2), 80-84(1994).

8. C. Vinagre, M. J. Martínez, L. F. Avendano, M. Landaeta, M. E. Pinto, Virology of infantile chronic recurrent parotitis in Santiago de Chile, J. Med Virol, 70(3), 459-462(2003).

9. S. Simani, A. Fayaz, P. Rahimi, N. Eslami, N. Howeizi, P. Biglari, A. Six fatal cases of classical rabies virus without biting incidents, Iran 1990-2010, J. Clin. Virol., 54(3), 251-254(2012).

10. G. B. Harnett, T. J. Farr, G. R. Pietroboni, M. R. Bucens, Frequent shedding of human herpesvirus 6 in saliva, J. Med Virol, 30(2), 128-130(1990).

11. J. O. Kang, Occupational infections of health care personnel in Korea, Hanyang Med. Rev., 31(3), 200-210(2011).

12. W. G. Lindsley, J. S. Reynolds, J. V. Szalajda, J. D. Noti, D. H. Beezhold, A cough aerosol simulator for the study of disease transmission by human cough-generated aerosols, Aerosol Sci Tech, 47(8), 937-944(2013).

13. S. T. El-Sayed, A. M. Ali, E. El-Sayed, W. G. Shousha, N. I. Omar, Characterization and potential antimicrobial effect of novel chitooligosaccharides against pathogenic microorganisms, J. Appl. Pharm. Sci., 7, 6-12(2017).

14. J. S. Jang, S. H. Hwang, Evauation of Hygienic Status of High School Foodservice using ATP Bioluminescence Assay \& Microorganism Test Strips, Korean J. Food \& Nutr., 28(5), 918-925(2015).

15. D. K. Jeong, E. S. Lyu, The microbiological evaluation of environments and facilities at food service operations in elementary school, J. Korean Soc Food Sci Nutr, 31(2), 216-220(2002).

16. J. Y. Lee, H. U. Im, H. J. Yun, H. R. Lee, A Study on the Quantitative Analysis of Fluorescent Whitening Agents in the Paper, Proceedings of the Korea Technical Association of the Pulp and Paper Industry Conference, J. of Korea TAPPI, Yongin, pp. 233-239(2005).

17. Y. S. Kim, H. K. Moon, S. I. Kang, E. J. Nam, Verification of the suitability of the ATP luminometer as the monitoring tool for surface hygiene in foodservices, Korean J. Food \& Nutr., 39(11), 1719-1723(2010).

18. R. Fushimi, M. Takashina, H. Yoshikawa, H. Kobayashi, T. Okudo, S. Nakata, M. Kaku, Comparison of adenosine triphosphate, microbiological load, and residual protein as indicators for assessing the cleanliness of flexible gastrointestinal endoscopes, Am. J. Infect. Control, 41(2),
161-164(2013).

19. A. Osimani, C. Garofalo, F. Clementi, S. Tavoletti, L. Aquilanti, Bioluminescence ATP Monitoring for the Routine Assessment of Food Contact Surface Cleanliness in a University Canteen, Int. J. Environ. Res. Public Health, 11(10), 10824-10837(2014).

20. N. S. Jakubovics, Saliva as the Sole Nutritional Source in the Development of Multispecies Communities in Dental Plaque, Metabolism and Bacterial Pathogenesis, T. Conway, P. Cohen (Eds.), ASM PRESS, Washington, DC., pp. 263 277(2015).

\section{Declaration of Competing Interest}

This work was supported by the 2021 Dream Academic Semester Program of Konkuk University.

\section{Authors and Contribution Statement}

\section{Sung Woo Yang}

Department of Biological Engineering, Konkuk University, Undergraduate researcher, ORCID (1) 0000-0001-5612-0077: The observer, Sample handling, Data analysis, Investigation, Methodology, Project administration, Writing original draft

\section{Seung Hyeon Reo}

Department of Biological Engineering, Konkuk University, Undergraduate researcher, ORCID (i) 0000-0003-3085-3250: The observer, Sample handling, Data analysis, Investigation, Methodology, Visualization

\section{Seung Jun Kim}

Department of Biological Engineering, Konkuk University, Undergraduate researcher, ORCID (D) 0000-0003-3075-819X: The observer, Sample handling, Investigation, Methodology

\section{Jeong Wook Jo}

Department of Biological Engineering, Konkuk University, M.S. Candidate, ORCID 이 0000-0002-0782-4913: The observer, Sample handling, Investigation, Methodology, Resources, Writing-review \& editing

\section{Yong-Keun Choi}

Department of Biological Engineering, Konkuk University, Ph.D., ORCID시 0000-0002-4535-8044: Methodology, Resources, Validation

\section{Hak Jin Song}

Department of Biological Engineering, Konkuk University, Ph.D. Candidate, ORCID 10 0000-0001-8263-2703: Methodology, Resources, Validation 


\section{Kyung Bin Oh}

Department of Biological Engineering, Konkuk University, M.S. Candidate, ORCID (0) 0000-0001-9445-1125: Bacteria analysis, Writing-review \& editing, Validation

\section{Ju Yeon Lee}

Department of Biological Engineering, Konkuk University, M.S. Candidate, ORCID 지 0000-0001-6659-0937: The observer, Bacteria analysis, Visualization, Validation

\section{Yunseok Jung}

Department of Beauty \& Cosmetology, Jeju University, Professor, ORCID® 0000-0002-0039-6370: Microorganisms analysis, Writingreview \& editing, Validation

\section{Hyung Joo Kim}

Department of Biological Engineering, Konkuk University, Professor, ORCID 이 0000-0001-6311-3748: Project management, Data analysis, Investigation, Methodology, Writing-review \& editing 